\title{
An Analysis of Perception and Uptake of Insurance Products among Medium-low Income Earners in Kenya
}

\author{
Charles Okeyo Owuor
}

School of Business and Economics, Faculty of Commerce, Kabarak University, Kenya

Copyright $\bigcirc 2016$ by authors, all rights reserved. Authors agree that this article remains permanently open access under the terms of the Creative Commons Attribution License 4.0 International License

\begin{abstract}
Although the insurance industry in Kenya has been growing in investment, there have been fundamental challenges in the number of new clients being recruited thus low penetration levels have been reported. The fast market growth notwithstanding, penetration rates remain low, at just $3 \%$ of GDP in 2013, 2014 and 2015 is still far below other developing economies. The high level of growth along low levels of penetration could lead the Kenyan insurance industry in crises in the near future. Therefore it is necessary to investigate into the trends in insurance uptake and the contributing factors. This study was designed to analyze perception and uptake of insurance products among medium-low income earners in Kenya on the basis that insurance penetration in Kenya is severely limited, which could have been as a result of the insured perception. The study was conducted using the explanatory research design. Primary data was collected using questionnaires administered to teachers using the drop and pick method. Quantitative data analysis was done using multiple response analysis techniques, mean, mode, standard deviation, percentages and frequencies. The study found out that perceptions on insurance played a key role in insurance uptake as the industry was marred by negative perceptions among potential customers hence low penetration. It is recommended that further research be conducted to evaluate customer experiences arising from insurance clients following the view held by majority insurance holders that they would not purchase insurance in the future.
\end{abstract}

Keywords Insurance Uptake, Perceptions, Teachers, Kenya

\section{Introduction}

Insurance is a key driver of economic development world over, while insurance companies represent a good proportion of the largest investments in various economies. In Kenya, the insurance industry is regulated by Insurance Regulatory Authority (IRA). The industry has grown significantly over the last decade and by the end of 2013 there were 47 insurance companies comprising of 10 long-term business insurers, 21 general business insurers, 16 composite insurers and 3 re-insurance companies. The market also comprised 161 licensed insurance brokers, 24 Medical Insurance Providers (MIPs), 3931 insurance agents and 2 locally incorporated re-insurers. In 2015, AKI revealed a continued growth in the insurance industry with insurance premiums amounting to 88 billion up from 76 billion in 2014 (AKI, 2015) [1]. The premium income under life insurance stood at 30 billion while the remaining 58 billion was from general business. The report however revealed a significantly high underwriting losses amounting to 105 million shillings. The same report revealed that $35 \%$ of the Kenyan insurance claims were fraudulent thus raising concerns on the future of insurance business in the country. Currently according to Insurance Regulatory Authority (IRA) report of 2015, Kenya has a total of 50 insurance companies, 3 reinsurance companies, 198 insurance brokers and 4 reinsurance brokers. There are a total of 5155 insurance agents in Kenya. The insurance penetration still stands at 3\% compared to its peercountries in the Sub-Saharan Africa region, below the African average of $3.8 \%$.

In the study by Finkelstein and McGarry (2006) [6] they considered the policyholder's private information on risk in the long-term medical care insurance market. Their findings indicated that two types of individuals buy insurance: Those with private beliefs that they are high risks and those with a strong taste for insurance. Ex post, the former are a higher risk and the latter a lower risk to the insurer. They concluded that, in aggregate, individuals with more insurance are not higher risks, and that an equilibrium with multiple forms of private information is unlikely to be efficient.

The issue of health risks as a determinant to health insurance participation is underlined by Morris, Devlin and Porklin, (2007) [10]. They held that the role of health insurance in addressing uncertainty in the demand for healthcare depends on attitude to risk. They maintained that an individual would pay for insurance as long as the utility it yields was at least as high as the utility they would achieve if they did not buy insurance. They see health insurance as a 
vehicle to remove uncertainty facing individuals with respect to the timing and magnitude of healthcare expenditure. For example, in Kenya, the National Hospital Insurance Fund (NHIF) is the primary provider of health insurance. Its mandate is to ensure that all Kenyans can access affordable health services. The NHIF registers all eligible citizens from both the formal and informal sector, and allows voluntary membership for those working in the informal sector.

\section{Problem Statement}

The IRA report of 2015 [4] revealed that the insurance sector has been involved in faster growth over the past years, with written premiums reaching compound annual growth rates (CAGR) of 15.1\% between 2004 and 2014. Although the insurance industry in Kenya has been growing in investment, there have been fundamental challenges in the number of new clients being recruited thus low penetration levels have been reported. The fast market growth notwithstanding, penetration rates remain low, at just $3 \%$ of GDP in 2013 [2], 2014 [3] and 2015 [4] is still far below other developing economies such as South Africa's with $14.16 \%$. The high level of growth along low levels of penetration could lead the Kenyan insurance industry in crises in the near future. Therefore it is necessary to investigate into the trends in insurance uptake and the contributing factors. This study was designed to analyze the perception and uptake of insurance products among medium-low income earners in Kenya.

\section{Objective of the study}

The main objective of the study was to analyze the perceptions and insurance uptake among medium low income earners in Kenya.

\section{Literature Review}

This study focused on various theories as discussed below

\section{Concept of uncertainty}

Most Kenyans work in farming, which leaves a lot of potential for climate risk and agricultural coverage, whereby there is a lot of uncertainty. Mas-Collel et al., (1995)[14] argued that uncertainty is the major foundation of insurance theory; two assumptions with respect to the consumers are made in the theory of uncertainty. They started arguing that the expected utility theorem is assumed to hold. It states that utility functions (satisfaction that is derived by the consumer) have the expected utility form (Neumann-Morgenstern utility function), i.e. aggregate utility is equal to the sum of the probability weighted utilities of a possible outcome. Secondly, individuals are assumed to be risk averse. This was supported by Dionne, (2000)[8] who held that individuals are willing to trade risk for certainty because it derives additional utility from a certain outcome. However, if the price for insurance is fair, i.e. the premium equals the expected indemnity payment of the insurance company, the individual prefers the certain outcome over any other outcome with non-zero variance (Schlesinger, 2006)[20]. Loewenstein et al. (2001)[12] argue that even if the price is not fair i.e. the insurance company keeps a profit, the individual might still opt for insurance because of potential non-pecuniary benefits (e.g. peace of mind) from being insured.

\section{Strategy Theory}

Chandler (1962)[5], defines strategy as the determination of the basic long term goals and objectives of an enterprise, and the adoption of courses of action and the allocation of resources necessary for carrying out those goals. Mintzberg, et al (2002)[15] defines strategy as a ploy, pattern, position and perspective. Marketing mix strategies would work well for Insurance penetration. The term marketing mix was coined by Neil Borden in the article 'The concept of marketing mix' which referred to the mixture of elements useful in pursuing a certain market response, especially in this study the consumer's perception. Further, the Pricing strategy is also important in Insurance perception and penetration strategy because most potential consumers of insurance products have low purchasing power and therefore there is need to offer insurance products in packages that are affordable. According to Insurance Regulatory Authority of 2015 on National Survey on enterprises perception of insurance in Kenya, educating people on importune of insurance and reducing the premiums would be the most effective way of increasing the penetration of insurance services in the country. Further the report revealed that awareness of insurance products is high in motor related products, followed by medical insurance and Theft for long term products. For short term products, low level of awareness was noted in marine, engineering, aviation, work men compensation act, agricultural insurance and liability. For long term products awareness of the education policy is high.

\section{Methodology}

The study was conducted using the explanatory research design because it helped to generate tentative explanations or hypotheses. The target population in this study was made up of all the teachers in public primary schools in Nakuru Sub-County. Teachers were preferred for this study because they were in an industry that would give a homogenous population for study. Further, teachers (in Kenya) comprise a large proportion of person in low income earners and middle -lower. According to the report by Kenya National Bureau of 2014/2015(KNBS 2014) [8] low income earn below Kenya shillings $23677 /=$ and middle income earn between Kenya Shillings $23677 /=$ to $120000 /=$. Currently, most insurance companies prefer low earners as they now go micro- insurance, therefore public primary school teachers form part of this population. The sampling frame was drawn from the list of public primary school teachers in Nakuru 
Sub-County obtained from the Nakuru Sub-County education office and the Nakuru Sub-County TSC Staffing Office. In total, there were 1124 public primary school teachers in 59 public primary schools in the Sub-County. A sample of 92 teachers was used, selected using stratified random sampling technique. The strata were based on the four Zones: in Eastern zone 25 teachers were selected, Western 22, Northern 23 and Southern 92 teachers.

The sample size was determined using the formula by Nassiuma (2000) [11]. The formula was suitable in determining an economical sample size from a larger population. Thus:

$$
n=\frac{N c v^{2}}{c v^{2}+(N-1) e^{2}}
$$

Where $\mathrm{n}=$ Sample size

$\mathrm{N}=$ Population (1124)

$\mathrm{C}_{\mathrm{v}}=$ Coefficient of variation (take between $21 \%-30 \%$ )

$\mathrm{e}=$ Tolerance at desired level of confidence, take 0.05 at 95\% confidence level

Therefore:

$$
n=\frac{1124 * 0.5^{2}}{0.5^{2}+(1124-1) 0.05^{2}}=91.83
$$

Thus $\mathrm{n}=92$ teachers.

Primary data was collected using questionnaires. The questionnaires were developed and administered to the selected teachers especially the heads teachers and deputy head teachers. Questionnaires elicited information from the public point of view on their level of awareness in relation to uptake of insurance products. Questionnaires were administered to teachers using the drop and pick method where teachers were allowed one to three days to complete. Quantitative data analysis was done using multiple response analysis techniques, mean, mode, standard deviation, percentages and frequencies.

\section{Results and Discussions}

Insurance uptake Among Teachers in Nakuru Sub County Respondents were asked to indicate whether they had acquired insurance policies before and from the findings, it was revealed that $73.6 \%$ of the school managers had purchased insurance cover before besides the mandatory NHIF. Basing on the previous purchase of insurance cover it was established it can be concluded that uptake was very high among school heads compared to the general uptake of 2\% within Nakuru County (IRA, 2015) [4] and 3.0\% nationally.

Further the study sought to know whether insurance purchase was voluntary of conditional within the category that had acquired it before.
Table 1. Voluntary Purchase of Insurance

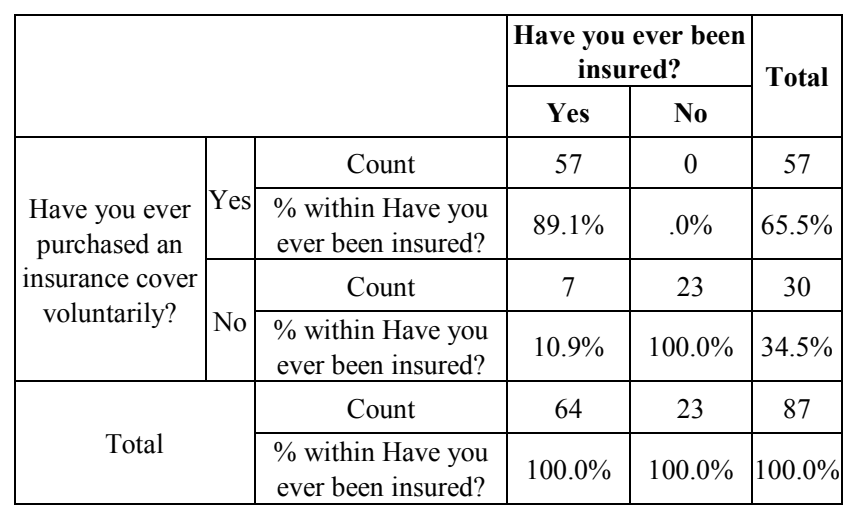

Out of the 64 school managers who had acquired insurance, $89.1 \%$ did so voluntarily while for $10.9 \%$ it was a requirement by other parties but not out of their own wish. This shows that indeed $65.5 \%$ of the school heads had purchased insurance voluntarily before. This still indicates a high level of insurance uptake among public primary school heads in Nakuru Sub-County compared to the national statistics.

The study was also interested to know whether policy holders would wish to purchase to purchase insurance in the future:

Table 2. Would You Wish to Have an Insurance Cover in Future?

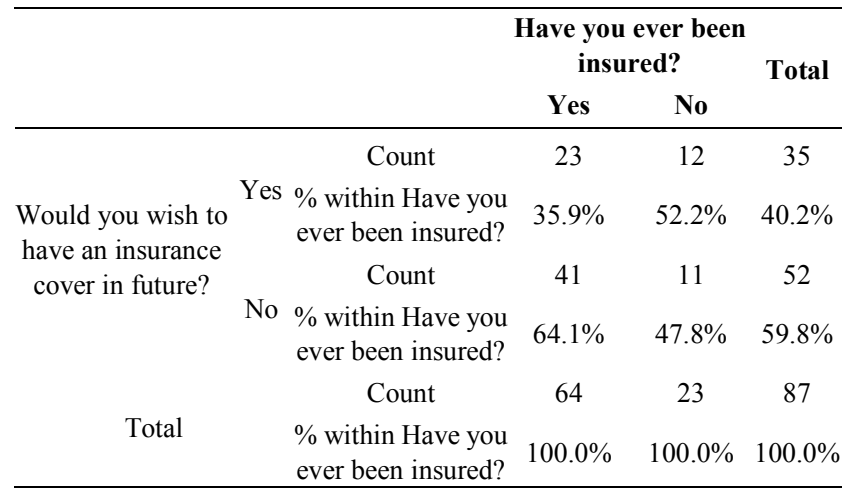

A majority of $64.1 \%$ school heads who had purchased insurance policies before indicated that they would not like to acquire insurance in the future. This number was higher than those who did not have policies in the past and would not like to purchase insurance in the future. This shows that existing customers were shying off from insurance contracts following their past experiences. This means that customers had had suffered the consequences of information asymmetry in favor of the insurance companies. Further in assessing the level of insurance uptake, the school heads were asked to indicate whether they would refer a friend to purchase insurance policies. 
Table 3. Advice a Friend to Purchase Insurance

\begin{tabular}{|c|c|c|c|c|c|}
\hline & \multicolumn{2}{|c|}{$\begin{array}{c}\text { Have you ever been } \\
\text { insured? }\end{array}$} & \multirow{3}{*}{$\begin{array}{c}\text { Total } \\
48\end{array}$} \\
\hline & & & Yes & No & \\
\hline \multirow{4}{*}{$\begin{array}{c}\text { Would you } \\
\text { advice a friend to } \\
\text { purchase an } \\
\text { insurance cover? }\end{array}$} & \multirow[b]{2}{*}{ Yes } & Count & 33 & 15 & \\
\hline & & $\begin{array}{c}\% \text { within Have } \\
\text { you ever been } \\
\text { insured? }\end{array}$ & $51.6 \%$ & $65.2 \%$ & $55.2 \%$ \\
\hline & \multirow[b]{2}{*}{ No } & Count & 31 & 8 & 39 \\
\hline & & $\begin{array}{c}\% \text { within Have } \\
\text { you ever been } \\
\text { insured? }\end{array}$ & $48.4 \%$ & $34.8 \%$ & $44.8 \%$ \\
\hline \multirow{2}{*}{\multicolumn{2}{|c|}{ Total }} & Count & 64 & 23 & 87 \\
\hline & & $\begin{array}{c}\% \text { within Have } \\
\text { you ever been } \\
\text { insured? }\end{array}$ & $100.0 \%$ & $100.0 \%$ & $100.0 \%$ \\
\hline
\end{tabular}

Majority of school heads who had purchased insurance cover before $(51.6 \%)$ would advice a friend to purchase insurance cover too. At the same time $65.2 \%$ of school heads who did not have insurance cover would advice a friend to have one. However, of concern was the $48.4 \%$ of the school heads who had purchased insurance cover and would not advice a friend to have a cover too. This implies that they were not confident with the insurance policies based on their experiences. These could be victims of bad insurance contracts emanating from insurance information asymmetry. The findings are in agreement with Churchill (2007) [5] who held that low penetration of insurance services has been attributed to a lack of confidence in insurance services. In the same wave length, the above results are supported by Makove (2011) [9] who also cited the lack of demand for insurance products for reasons of information asymmetry in the industry. When asked to indicate whether insurance policies were beneficial, the responses were as shown below:

Table 4. Whether insurance policies were beneficial to policy holders

\begin{tabular}{|c|c|c|c|c|c|}
\hline & \multicolumn{2}{|c|}{$\begin{array}{c}\text { Have you ever been } \\
\text { insured? }\end{array}$} & \multirow{2}{*}{ Total } \\
\hline & & & Yes & No & \\
\hline \multirow{4}{*}{$\begin{array}{c}\text { Are insurance } \\
\text { policies beneficial } \\
\text { to the policy } \\
\text { holder? }\end{array}$} & \multirow[b]{2}{*}{ Yes } & Count & 41 & 18 & 59 \\
\hline & & $\begin{array}{l}\% \text { within Have you } \\
\text { ever been insured? }\end{array}$ & $64.1 \%$ & $78.3 \%$ & $67.8 \%$ \\
\hline & \multirow[b]{2}{*}{ No } & Count & 23 & 5 & 28 \\
\hline & & $\begin{array}{l}\% \text { within Have you } \\
\text { ever been insured? }\end{array}$ & $35.9 \%$ & $21.7 \%$ & $32.2 \%$ \\
\hline \multirow{2}{*}{\multicolumn{2}{|c|}{ Total }} & Count & 64 & 23 & 87 \\
\hline & & $\begin{array}{l}\% \text { within Have you } \\
\text { ever been insured? }\end{array}$ & $100.0 \%$ & $100.0 \%$ & $100.0 \%$ \\
\hline
\end{tabular}

The results of cross tabulation on Table 4 indicated that majority of the school heads $(67.8 \%)$ appreciate that insurance was beneficial. More importantly is the $78.3 \%$ of school heads who did not have insurance before but understand that insurance was beneficial to them. However, there was a concern that $35.9 \%$ of the school heads who had acquired insurance policies before felt that it was not beneficial. This shows that there was increasing awareness and change of attitude towards insurance for persons who were not insured before. The negative attitude of those who had insurance policies before indicate the failure of insurance companies to deliver their promises to the customers' expectations which could be linked to informational asymmetries between the insurer and insurance where the insurance company had a higher advantage. The findings above concur with the study of Hardman (2012) [7] who argued that lack of information about the benefits of insurance allows people to be always wary of insurance and view it in a negative light, thus they prefer to rely on traditional arrangements or religious practices.

\section{Ownership of Insurable Property's}

The study sought also to find out whether there was any relationship between insurance uptake and ownership of insurable properties among public primary school heads.

Table 5. Vehicle Ownership and Insurance Uptake

\begin{tabular}{|c|c|c|c|c|c|}
\hline & \multicolumn{2}{|c|}{$\begin{array}{c}\text { Have you ever been } \\
\text { insured? }\end{array}$} & \multirow{3}{*}{\begin{tabular}{|c|} 
Total \\
51
\end{tabular}} \\
\hline & & & Yes & No & \\
\hline \multirow{4}{*}{$\begin{array}{c}\text { Do you own a } \\
\text { car }\end{array}$} & \multirow[b]{2}{*}{ Yes } & Count & 45 & 6 & \\
\hline & & $\begin{array}{l}\% \text { within Have you } \\
\text { ever been insured? }\end{array}$ & $70.3 \%$ & $26.1 \%$ & $58.6 \%$ \\
\hline & \multirow[b]{2}{*}{ No } & Count & 19 & 17 & 36 \\
\hline & & $\begin{array}{l}\% \text { within Have you } \\
\text { ever been insured? }\end{array}$ & $29.7 \%$ & $73.9 \%$ & $41.4 \%$ \\
\hline \multirow{2}{*}{\multicolumn{2}{|c|}{ Total }} & Count & 64 & 23 & 87 \\
\hline & & $\begin{array}{l}\% \text { within Have you } \\
\text { ever been insured? }\end{array}$ & $100.0 \%$ & $100.0 \%$ & $100.0 \%$ \\
\hline
\end{tabular}

The findings revealed that majority of the school heads who had insurance policies before also owned cars $(70.3 \%)$ while majority of those who did not have policies did not own cars. This implies that ownership of motor vehicles was associated with insurance uptake. Further, ownership of property was assessed in relation to insurance uptake.

Table 6. Ownership of Property and Insurance Uptake

\begin{tabular}{|c|c|c|c|c|c|}
\hline & & & \multicolumn{2}{|c|}{$\begin{array}{c}\text { Have you ever been } \\
\text { insured? }\end{array}$} & \multirow[t]{2}{*}{ Total } \\
\hline & & & Yes & No & \\
\hline \multirow{4}{*}{$\begin{array}{c}\text { Do you own } \\
\text { property }\end{array}$} & \multirow[b]{2}{*}{ Yes } & Count & 49 & 13 & 62 \\
\hline & & $\begin{array}{l}\% \text { within Have you } \\
\text { ever been insured? }\end{array}$ & $76.6 \%$ & $56.5 \%$ & $71.3 \%$ \\
\hline & \multirow[b]{2}{*}{ No } & Count & 15 & 10 & 25 \\
\hline & & $\begin{array}{l}\% \text { within Have you } \\
\text { ever been insured? }\end{array}$ & $23.4 \%$ & $43.5 \%$ & $28.7 \%$ \\
\hline \multirow{2}{*}{\multicolumn{2}{|c|}{ Total }} & Count & 64 & 23 & 87 \\
\hline & & $\begin{array}{l}\% \text { within Have you } \\
\text { ever been insured? }\end{array}$ & $100.0 \%$ & $100.0 \%$ & $100.0 \%$ \\
\hline
\end{tabular}

The findings on table 6 shows that majority of public primary school heads who owned properties also had insurance policies (76.6\%). However, $56.5 \%$ of those who were not insured also owned properties. This implies that 
ownership of properties was not a key determinant of insurance uptake. Comparing this finding with ownership of cars, it can be argued that uptake of property insurance was voluntary while that of motor vehicles was compulsory. Thus ownership of motor vehicle was associated more with insurance uptake than property ownership.

Common Types of Insurance Policies Purchased by Teachers

The common types of insurance policies purchased by public primary school heads in Nakuru Sub County was determined a multiple response question where a holder of insurance policy was allowed to select more than one policy held.

Table 7. Insurance Policy Penetration

\begin{tabular}{|c|c|c|c|}
\hline & \multirow{2}{*}{\begin{tabular}{|c|} 
Responses \\
$\mathbf{N}$ \\
\end{tabular}} & \multirow{2}{*}{$\begin{array}{c}\text { Percent of } \\
\text { Cases }\end{array}$} \\
\hline & & & \\
\hline \multirow{6}{*}{$\begin{array}{c}\text { Type of policy } \\
\text { owned }^{\mathrm{a}}\end{array}$} & Life insurance & 44 & $72.1 \%$ \\
\hline & Education insurance & 45 & $73.8 \%$ \\
\hline & Motor insurance & 36 & $59.0 \%$ \\
\hline & Fire Insurance & 8 & $13.1 \%$ \\
\hline & Medical Insurance & 37 & $60.7 \%$ \\
\hline & Personal Accident insurance & 15 & $24.6 \%$ \\
\hline \multicolumn{2}{|r|}{ Total } & 185 & $303.3 \%$ \\
\hline
\end{tabular}

a. Dichotomy group tabulated at value 1 .

The findings in insurance penetration revealed that education policy was the most common insurance among primary school teachers in which $73.8 \%$ of those insured had education policy for their children. Secondly was the life insurance where $72.1 \%$ had life cover followed by medical insurance cover which was subscribed by $60.7 \%$ of school heads with insurance cover. Motor insurance was also common as it was acquired by $59.0 \%$ of the staff with insurance. Personal accident cover was less common where only $24.6 \%$ of school heads with insurance were covered. The least adopted cover was the fire insurance subscribed by only $13.1 \%$. From this finding, it can be seen that the penetration of life insurance and medical insurance covers were higher among teachers as opposed to other forms of insurance covers

Other than the policies held at the time of the study, the researcher sought to know, the insurance prospects of teachers. This was by determining their intentions to purchase insurance cover in the future.

Table 8. Type of Policy Intended for Purchase In Future

\begin{tabular}{|c|c|c|c|}
\hline & Responses & \multirow{2}{*}{$\begin{array}{l}\text { Percent of } \\
\text { Cases }\end{array}$} \\
\hline & & $\mathbf{N}$ & \\
\hline \multirow{6}{*}{$\begin{array}{c}\text { Policy intended for } \\
\text { purchase }^{\mathrm{a}}\end{array}$} & Life insurance & 18 & $47.4 \%$ \\
\hline & Education insurance & 11 & $28.9 \%$ \\
\hline & Motor insurance & 5 & $13.2 \%$ \\
\hline & Fire Insurance & 10 & $26.3 \%$ \\
\hline & Medical Insurance & 21 & $55.3 \%$ \\
\hline & Personal Accident insurance & 15 & $39.5 \%$ \\
\hline \multicolumn{2}{|r|}{ Total } & 80 & $210.5 \%$ \\
\hline
\end{tabular}

a. Dichotomy group tabulated at value 1 .
The prospects for medical insurance cover were promising in the future since $55.3 \%$ of the school heads without insurance cover had intentions to acquire it while $47.4 \%$ intended to purchase life insurance cover. The third most promising cover was the Personal Accident insurance since $39.5 \%$ of the uninsured indicated their interest to purchase it in the future. Teachers would also like to have education policies and fire insurance in the future although a few were interested $28.9 \%$ and $26.3 \%$ respectively. Motor insurance was the least cited by only $13.2 \%$. These findings point out to existence of unmet insurance demand skewed to medical, and life insurance cover.

For those teachers who had no insurance policies in place, the study sought to establish the reasons as to why they had not purchased insurance covers. Various opinions were raised in which some teachers cited multiple reasons.

Table 9. Reasons for Non Purchase of Insurance

\begin{tabular}{|c|c|c|c|}
\hline & \multirow{2}{*}{\begin{tabular}{|c|} 
Responses \\
$\mathbf{N}$ \\
\end{tabular}} & \multirow{2}{*}{$\begin{array}{c}\text { Percent of } \\
\text { Cases }\end{array}$} \\
\hline & & & \\
\hline \multirow{12}{*}{$\begin{array}{l}\text { Reasons for } \\
\text { non purchase } \\
\text { of insurance }\end{array}$} & Have never heard about insurance & 2 & $9.1 \%$ \\
\hline & $\begin{array}{c}\text { Have heard my colleagues/other } \\
\text { people talk negatively about } \\
\text { insurance }\end{array}$ & 16 & $72.7 \%$ \\
\hline & $\begin{array}{c}\text { There are no insurance policies that } \\
\text { meet my needs }\end{array}$ & 2 & $9.1 \%$ \\
\hline & Insurance is expensive & 20 & $90.9 \%$ \\
\hline & $\begin{array}{c}\text { I do not know the insurance } \\
\text { products available }\end{array}$ & 4 & $18.2 \%$ \\
\hline & \begin{tabular}{|c} 
I do not have a good understanding \\
of insurance \\
\end{tabular} & 3 & $13.6 \%$ \\
\hline & Compensation is complicated & 20 & $90.9 \%$ \\
\hline & It is against my beliefs & 1 & $4.5 \%$ \\
\hline & $\begin{array}{l}\text { Insurance companies do not give } \\
\text { compensation. }\end{array}$ & 4 & $18.2 \%$ \\
\hline & I cannot afford the cost of cover & 3 & $13.6 \%$ \\
\hline & I do not trust insurance companies & 12 & $54.5 \%$ \\
\hline & I believe God Covers me & 2 & $9.1 \%$ \\
\hline & Total & 89 & $404.5 \%$ \\
\hline
\end{tabular}

a. Dichotomy group tabulated at value 1 .

The findings revealed a general perception that insurance was expensive to afford, and that compensation in case of a risk happening was complicated. These reasons were cited $90.9 \%$ of the teachers who had no insurance policies. $72.7 \%$ indicated that they failed to purchase insurance because they overheard negative talks about insurance from colleagues while $54.5 \%$ do not trust insurance companies which are the main reasons as to why they did not consider purchasing insurance. Other reasons that were cited responsible for failure to take insurance include the lack of information about insurance products available (18.2\%), 13.6\% have no good understanding of insurance, some $9.1 \%$ argued that they have not heard of insurance and an equal number believes that there is no insurance policy that meets their needs while $9.1 \%$ believe in Gods cover as opposed to 
insurance cover. From the findings it can be observed that the most outstanding reasons for low uptake of insurance was related to information held by the customer. The perception that insurance was very expensive, failure to trust insurance, misinformation on compensation and negative talk all work together to discourage insurance uptake. In the foregoing, the findings herein above is further in support with the study of Hardman (2012) [7] who held that lack of information about the benefits of insurance allows people to be always wary of insurance and view it in a negative light, thus they prefer to rely on traditional arrangements or religious practices. Therefore it can be concluded that information asymmetry was rampant in the Kenyan insurance sector as a key contributor for low uptake of insurance.

\section{Summary of the Findings}

Based on the results on insurance uptake it can be seen that majority of head teachers have purchased insurance cover before besides the mandatory NHIF. Further, of those who had acquired insurance before, majority did so voluntarily. However, majority of teachers who acquired insurance before would not want to have insurance in the future although they would advice others to have it. This indicates a negative opinion towards insurance services. This could have arisen from the bad customer experiences in the course of their contracts. However, the study did not seek to know why customers were not happy with their insurance companies. Majority of those who had insurance also owned cars thus ownership of motor vehicles was closely associated with insurance uptake.

The most common insurance policies purchased by primary school teachers were education policy for their children, life insurance, medical insurance cover and motor insurance respectively. Property and business insurance were less common and their future did not appear bright owing to the customers' current position. The prospects for medical insurance cover were promising in the future followed by life insurance cover, personal accident insurance and education policies and fire insurance. The main reasons cited for failure to purchase insurance covers were that it was expensive, they overheard negative talks on insurance, no good understanding of insurance, lack of information about insurance products available and that they do not trust insurance companies. The above reasons majorly resulted into negative perception on insurance which inform customers on their purchase patterns.

\section{Conclusions and Recommendations}

The findings of this study imply that uptake of insurance was relatively high among primary school heads although in their view; they would not purchase insurance in the future. The teachers (now consumers) perceive that insurance uptake is mainly suits for those with high income and therefore penetration or risk sharing was very low. They also considered that the premium rate is not affordable by middle income earners. Perceptions on insurance played a key role in insurance uptake as the industry was marred by negative perceptions among potential customers. That notwithstanding teachers who had purchased insurance before were not willing to do so in the future which implies that despite the much marketing initiatives by insurance companies, the negative perception was still a dominant player in uptake. So the service providers have to look on the product innovations and appropriate distribution channel to make insurance uptake reach more effectively. There is need for a further research to evaluate customer experiences arising from insurance clients following the view held by majority insurance holders that they would not purchase insurance in the future.

\section{REFERENCES}

[1] AKI (2015) Annual Report 2015. Nairobi: Association of Kenya Insurance

[2] IRA (2013) Annual Report 2013. Nairobi: Insurance Regulatory Authority

[3] IRA (2014) Annual Report 2014. Nairobi: Insurance Regulatory Authority

[4] IRA (2015) Annual Report 2015. Nairobi: Insurance Regulatory Authority.

[5] Chandler,A.D. (1962) Strategy and structure, MIT Press

[6] Churchill, C., Reinhard, D. \& Qureshi, Z. (2006). Into Action: Micro insurance - Making insurance work for the poor, Report Summary Micro insurance conference, Munich.

[7] Churchill, C (2007) Insuring the Low-Income Market: Challenges and Solutions for Commercial Insurers. The Geneva Papers on Risk and Insurance 32:401-412.

[8] Dionne, G. et al. (2000). Handbook on Insurance. Boston: Kluwer Academic Publishers

[9] Finkelstein, A. and McGarry, K. (2006) Multiple Dimensions of Private Information: Evidence from the Long-Term Car Insurance Market. American Economic Review 96(4), 938-958.

[10] Hardman, B.(2012) Micro-insurance \& Climate Change. A4ID: Advocates for International Development (Lawyers Eradicating Poverty). Last Accessed June 26, 2015

[11] Kenya National Bureau Report 2014/2015, Nairobi, Kenya.

[12] Loewenstein, G., Hsee C., Weber E. and Welch N. (2001). Risk as Feelings. Psychological Bulletin, Vol 127(2), 267-286.

[13] Makove, S. (2011) African Policy Approaches: Microinsurance in Kenya. Paper presented at AIO - A2ii Regulators' Workshop, Victoria Falls, Zimbabwe, May 26. 
[14] Mas-Colell, A., Whinston \& M., Green, J (1995). Microeconomic Theory. New York: Oxford University Press

[15] Mintzberg, H., Joseph B. Lampel, James B,Sumantra G.(2002).The strategy process(4th Ed),Pearson Education Publishers' Ltd

[16] Morris S, Devlin N and Porklin D. (2007). Economic Analysis in health care England. John Wiley and Sons Ltd.

[17] Mossin, J., (1968). Aspects of Rational Insurance Purchasing. Journal of Political Economy. Vol. 76, 533-568.

[18] Nassiuma, D. (2000). Survey sampling: Theory and methods.
Njoro, Kenya: Egerton University Press.

[19] Roth, J. \& Athreye, V (2005). TATA-AIG Life Insurance Company Ltd. - India. CGAP Working Group on Microinsurance, Good and Bad Practices in Microinsurance, Case Study No. 14

[20] Schlesinger, H. (2006). Mossin's Theorem for Upper-Limit Insurance Policies. The Journal of Risk and Insurance. Vol 73 (2), 297-301.

[21] Vaughan.E. \& Vaughan. T (2008). Fundamentals of risk and insurance, 111. River Street, Hoboken, John Wiley and Sons. 